\title{
Merkel Cell Carcinoma pTis TNM Finding v7
}

National Cancer Institute

\section{Source}

National Cancer Institute. Merkel Cell Carcinoma pT is TNM Finding v7. NCI Thesaurus.

Code $C 88503$.

Merkel cell carcinoma with a finding of in situ primary tumor. (from AJCC 7th Ed.) 